
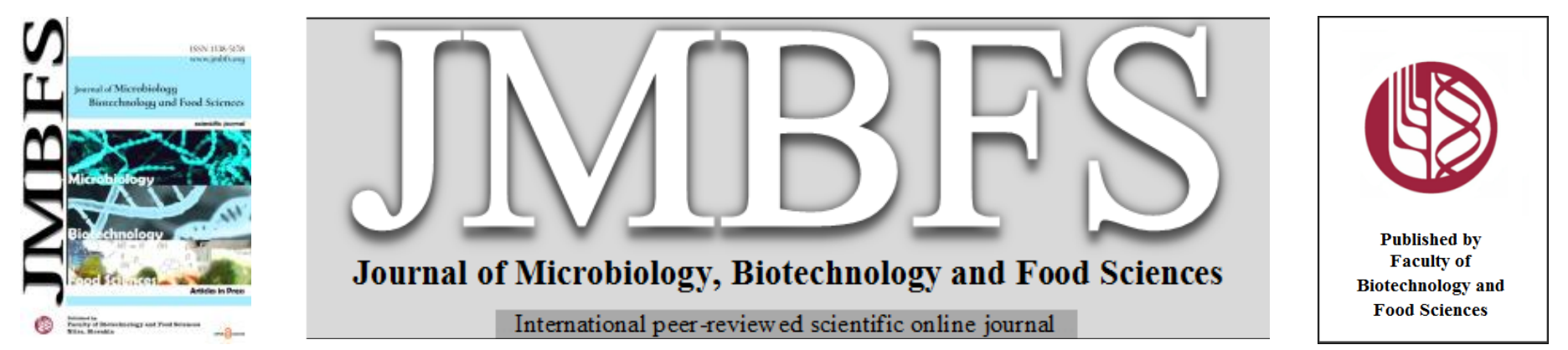

\title{
FURFURAL, HYDROXYMETHYLFURFURAL AND FUROSINE AS MAILLARD REACTION MARKERS IN FRUIT BASED FOODS INCLUDING JAMS AND BABY FOOD
}

\author{
Agnieszka Nowak* , Beata Janoszka, Magdalena Szumska, Krystyna Tyrpień-Golder
}

Address(es): MSc Agnieszka Nowak,

Medical University of Silesia, Katowice, Poland, Faculty of Medical Sciences in Zabrze, Department of Chemistry, Jordana Street 19, 41-808 Zabrze, phone number: 0322755188 .

*Corresponding author: agnieszkanowak@sum.edu.pl

https://doi.org/10.15414/jmbfs.1384

\section{ARTICLE INFO}

Received 7. 3. 2019

Revised 8. 6. 2021

Accepted 16. 6. 2021

Published 1. 12. 2021

Regular article OPEN $\partial_{\text {ACCESS }}$

\section{ABSTRACT}

The Maillard reaction occurs between amino acids and reducing sugars and goes through a series of reactions to form various products (MRPs - Maillard reaction products). The reaction is well-known for browning it causes in thermally treated foodstuffs. Many factors influence the type of MRPs formed: $\mathrm{pH}$, sugar content, and processing conditions (temperature, pressure, duration). The compounds formed exhibit different biological properties, some are harmful to organisms and some are considered to be beneficial.

MRPs may also occur in jams and fruit-based baby foods at the level of $\mathrm{mg} / 100 \mathrm{~g}$. As these products are popular among consumers at every age including babies, many studies focus on the evaluation of Maillard reaction on their quality. In this review we have discussed the occurrence, factors affecting the process of formation of chosen MRPs, furosine and hydroxymethylfufural, in fruit jams as well as their influence on the organism.

Keywords: Maillard reaction, fruit jam, MRPs, furosine, furfural, hydroxymethylfurfural

\section{INTRODUCTION}

The Maillard Reaction (MR), named after its discoverer Louis Maillard from France, actually consists of a number of complex chemical reactions which require amino acids and reducing sugars as substrates. It can occur at room temperature but is intensified at higher temperatures so it is mostly associated with processing and heating of food rich in sugars and amino acids (Martins, Jongen and van Boekel, 2000; Nahid and Niaz, 2015; Parker, 2012). The reaction leads to the creation of various products of different properties generally called MRPs Maillard Reaction Products. Temperature and time of heating, as well as $\mathrm{pH}$, moisture and water activity influence the chemical composition of the Maillard Reaction Products (Parker, 2012). It is a kind of non-enzymatic browning which forms dark pigments in processed food, as well as volatile substances which improve the flavour and appearance of the food (Martins et al., 2000; RadaMendoza, Olano and Villamiel, 2002a). Colour and taste are modified, usually resulting in significantly different aspects of manufactured products (Martins $\boldsymbol{e}$ al., 2000). MRPs are detectable in meat, dough, cereals, coffee and many more foodstuffs undergoing baking, toasting, roasting and frying (Martins et al., 2000; Murkovic and Pichler, 2006; Plaza, Östman and Tareke, 2016; RadaMendoza, Olano and Villamiel, 2002b; Švecová and Mach, 2017; Vorlova, Borkovcová, Kalábová, and Vecerek, 2006).

Studies proved that MRPs also occur in processed fruit products, especially those rich in sugar such as jams or dried fruit (Murkovic and Pichler, 2006; Vorlova et al., 2006). There are various forms of fruit preserves available on the market, as fruits are perishable and some of them are obtained only seasonally. Fruit are present in baby foods too, which are similar to jams in their properties (Cendrowski, Ścibisz and Mitek, 2011; Flores and del Castillo, 2016; RadaMendoza et al., 2002a; Tomas et al., 2017). As baby foods undergo therma treatment leading to Maillard reaction occurrence too, their quality needs to be carefully studied and controlled (Rada-Mendoza et al., 2002b).

The Maillard reaction can be described as a series of reactions with many possible pathways and final products. Thus many sophisticated schemes and explanations of Maillard reaction have been elaborated through years of research (Henning and Glomb, 2016; Martins et al., 2000). In Figure 1 there is a simplified scheme of the Maillard reaction. The reaction can be briefly characterized in a few steps:
1. Reaction of reducing sugars' carbonyl group (glucose, fructose, disaccharides hydrolysis products) with a free amino group (present in amino acids or proteins, mainly the $\varepsilon$-amino group of lysine, but also the $\alpha$-amino groups of terminal amino acids in proteins). As a result a Schiff base is formed which is a tautomeric form of $\mathrm{N}$-substituted glycosylamine.

2. N-substituted glycosylamine undergoes rearrangement and gives ketosamine or aldosamine. Amadori rearrangement product (1-amino-1-deoxy-2-ketose) is formed if aldoses are react or Heyns rearrangement product is formed (2amino-2-deoxyaldose) if ketoses are used. One of the Amadori rearrangement products is furosine (Figure 2) formed when the $\varepsilon$-amino group of lysine react with the carbonyl group of glucose (Erbersdobler and Somoza, 2007; Martins et al., 2000; Nahid and Niaz, 2015; Parker 2012).

3. Amadori rearrangement products degrade, following pathway which depend on $\mathrm{pH}$. It is accompanied by dehydration.

a. If $\mathrm{pH}$ is 7 or below then furfural or hydroxymethylfurfural (Figure 2) among others are formed.

b. If $\mathrm{pH}$ is higher than 7 then 4-hydroxy-5-methyl-2,3-dihydrofuran-3-one and highly reactive acetol, furaneol, maltol, pyruvaldehyde and diacetyl among other are formed.

4. All these compounds mentioned above are highly reactive. Carbonyl groups condense with free amino groups and these products undergo further transformations. Dicarbonyl compounds will react with amino acids with the formation of aldehydes and a-aminoketones.

5. The most distinctive products formed are melanoidins, which are polymeric compounds of high molecular weight, characteristic brown colour and rich in various chemical groups (e.g. carboxyl, ester, amine, hydroxyl and many more). Structure of melanoidins has still not fully been determined (Martins et al., 2000; Nahid and Niaz, 2015; Parker 2012).

Hydroxymethylfurfural (HMF) is commonly used as Maillard reaction indicator in thermally processed food (Cendrowski et al., 2011; Erbersdobler and Somoza, 2007; Garza, Ibarz, Pagânand Giner, 1999; Rada-Mendoza et al., 2002a). HMF itself can also be produced through L-ascorbic acid degradation and hexoses (fructose and glucose) dehydration (Bharate and Bharate, 2014; Cendrowski et 


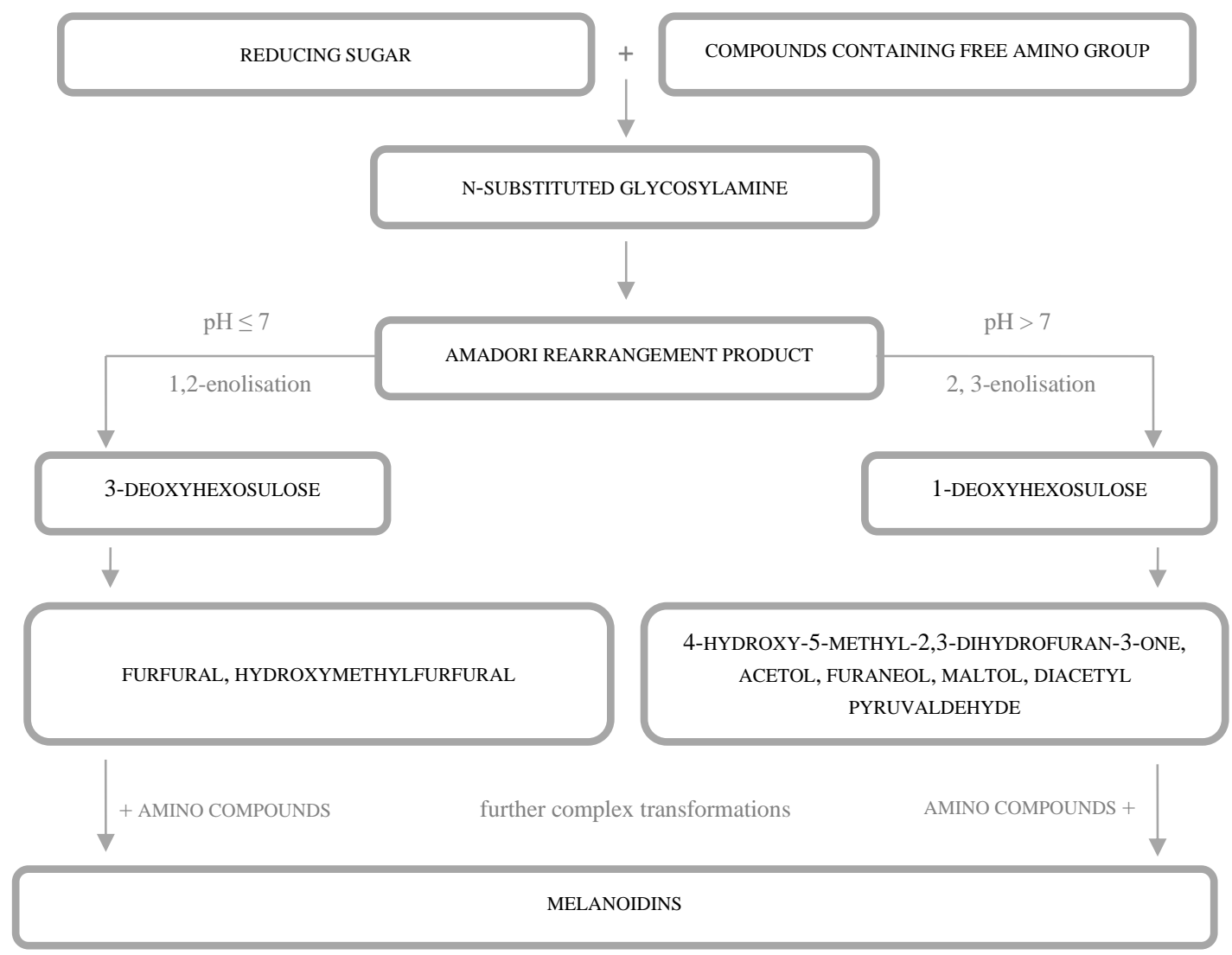

Figure 1 Simplified scheme of the Maillard reaction
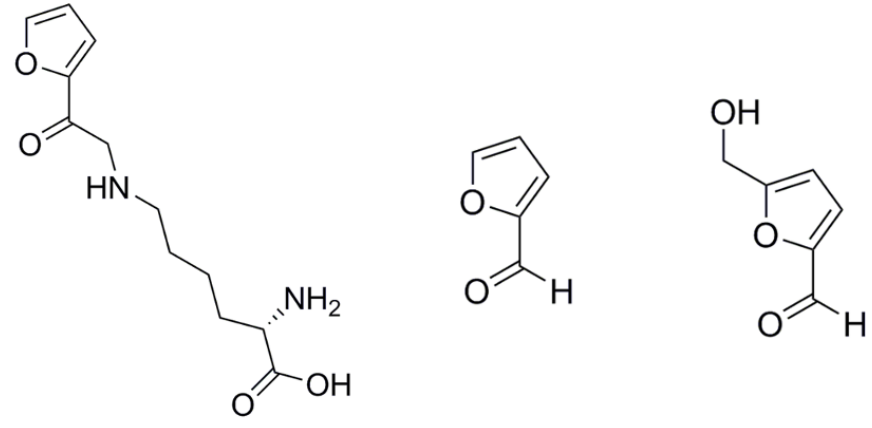

Figure 2 Structures of furosine (left), furfural (middle) and hydroxymethylfurfural (right)

The Products of Maillard Reaction have a wide range of impact on the functions of organisms. As the reaction does not follow a simple pathway and it is not easily controlled during thermal treatment of food, pigments are not the only products. The complex network of interdependent reactions affect nutritional value, digestibility and - crucially - the toxicity of the food product. The safety of the food is affected in two different ways - in formation of MRPs with antioxidan properties (e.g. melanoidins) and, the formation of toxic substances (for example HMF) (Martins et al., 2000; Monien, Frank, Seidel and Glatt, 2009;_Monien, Engst, Barknowitz, Seidel and Glatt, 2012; Šebeková and Brouder Šebeková, 2018).

The aim of this review is to sum up the current state of knowledge about the factors influencing the formation of furosine, furfural and hydroxymethylfurfural in thermally treated fruit derivatives: jams and baby foods, and to describe their impact on human health.

\section{OCCURRENCE OF CHOSEN MRPS IN FRUIT PRODUCTS}

Jam production consists of long periods of heating at high temperature and the plant material is usually rich in sugar (Murkovic and Pichler, 2006). Some MRPs require up to 3 hours to be formed and reach plateau. Jams prepared in traditional ways can be thermally treated even longer than 3 hours (Cendrowski and Mitek, 2012; Parker, 2012; "Powidła śliwkowe z węgierek," 2018; "Powidła śliwkowe lowickie," 2018). As fruit jams have acidic $\mathrm{pH}$, the Maillard Reaction follows the 1,2-enolisation pathway leading to the formation of significant amounts of HMF (Figure 1) (Murkovic and Pichler, 2006). Steber et al. (1987) proposed that less than $5 \mathrm{mg}$ of $\mathrm{HMF}$ in $100 \mathrm{~g}$ of jam indicates the proper jam preparation procedure (Steber and Klostermeyer, 1987). Based on reference data it can be stated that HMF concentration in jams depends on type of sample and varies from less than 0.1 to almost $120 \mathrm{mg} / 100 \mathrm{~g}$ (Cendrowski, 2012; Murkovic and Pichler, 2006). Fruit-based baby foods exhibit lower concentrations of this compound (from a nondetectable amount up to $0.8 \mathrm{mg} / 100 \mathrm{~g}$ ) (Rada-Mendoza et al., 2002b). Among fruit products, the highest concentrations of HMF are detected in dried fruits and juices obtained from dried fruit (Murkovic and Pichler, 2006). Conversely, juice produced from raw pomegranates by Sabanci et al. (2018) contained no HMF (Sabanci, Cevik, Cokgezme, Yildiz and Icier, 2018). Generally, the intensity of the Maillard Reaction, and therefore levels of HMF in fruit based food is considered high. It is worth noting that concentration of this compound is higher in some processed fruit products than in other foodstuffs like bread or meat, as shown in Table 1. The exceptions are caramel products, where HMF concentration can reach up to almost $1 \mathrm{~g} / 100 \mathrm{~g}$ of product.

HMF is usually not detected in fresh honeys or can be present in them only in trace amounts, below $0.1 \mathrm{mg} / 100 \mathrm{~g}$ (Kesić et al., 2014; Missio da Silva et al., 2016). The content of HMF in honey is significantly influenced by temperature, time and storage conditions as well as the geographical factor. The formation of HMF depends on the floral oigin of honey, $\mathrm{pH}$, total acidity, moisture, type and content of reducing sugars. The highest concentrations of HMF were determined in honeys from tropical countries (Table 1) (Shapla et al., 2018).

While HMF is commonly used as a Maillard Reaction marker there are two other compounds proposed as indicators of the reaction in fruit baby foods and jams: furfural and furosine. They are determined less often in studies on MRPs in food Furfural is created in Maillard reaction at the same stage as HMF (Figure 1). Cendrowski et al. (2011) noted concentrations of this compound varying from about 0.0025 to $0.021 \mathrm{mg} / 100 \mathrm{~g}$ of product in jams (Cendrowski et al., 2011; Rada-Mendoza et al., 2002a; 2004) examining furosine levels in various food samples, detected compound concentrations in the range between 15.1 to 629.3 $\mathrm{mg} / 100 \mathrm{~g}$ of protein in fruit jams and from 44.0 to $178.0 \mathrm{mg} / 100 \mathrm{~g}$ of protein in baby foods (Rada-Mendoza et al., 2002a; Rada-Mendoza et al., 2004). In the 
Table 2 concentrations of HMF and furosine in various jams and baby fruit foods are shown.

Table 1 Comparison of HMF concentration in jams, baby foods and other food products (Codex Alimentarius Commission, 2001; Kesić et al., 2014; Murkovic and Pichler, 2006; Plaza et al., 2016; Rada-Mendoza et al., 2002b; Shapla et al., 2018; Švecová and Mach, 2017; Vorlova et al., 2006)

\begin{tabular}{lc}
\hline Food product & Amount of HMF [mg/ 100 g] \\
\hline Dried fruits & 2.50 to 290.0 \\
Juices obtained from dried fruit & trace amount -120 \\
\hline Jams & not detectable -0.98 \\
\hline Fruit baby foods & not detectable -3.50 \\
\hline Baby biscuits & 0.114 \\
\hline Baby gruel & $11.0-950.0$ \\
\hline Caramel products & $0.5-42.0[\mathrm{mg} / 100 \mathrm{ml}]$ \\
\hline Coffee & $\leq 41.0$ \\
\hline Bread & $<0.09$ \\
\hline Meat products & $0.0-11.2$ \\
\hline Honey from Europe & $0.0-113.2$ \\
Honey from Africa and Asia & $0.0-11.5$ \\
Honey South and North America &
\end{tabular}

\section{FACTORS INFLUENCING THE FORMATION OF MRPS IN FRUIT PRODUCTS}

Jams contain fruits (fresh or already processed), fruit juice, sweetening agents, sometimes also texture modifiers (pectins), acids (e.g. citric acid) and additional antioxidants (Cendrowski, 2012; Rada-Mendoza et al., 2002a; Tomas et al., 2017).

In jam manufacturing, a few major elements of the process influence the pathway of Maillard Reaction: sugar content, pressure along with temperature, processing time, $\mathrm{pH}$ and storage conditions.

\section{Sugar and fruit content}

Sugar content influences moisture and water activity in food. Lower sugar content means not only less reactant available, but also higher moisture and water activity, which affect intensity of the Maillard Reaction (Makawi et al., 2009; Parker, 2012; Rada-Mendoza et al., 2002a).

In the Table 2 based on the reference data HMF and furosine concentrations in jams and fruit-based baby food were shown and compared according to the sugar content. It can be noticed that jams of high sugar content $(60 \%$ or more) contained more HMF $(0.45-15.96 \mathrm{mg} / 100 \mathrm{~g}$ of product $)$ than other samples $(0.08-7.5$ $\mathrm{mg} / 100 \mathrm{~g}$ of product). In almost all products of low sugar content (40\% or less) HMF concentration was lower than $0.7 \mathrm{mg} / 100 \mathrm{~g}$. HMF content in fruit-based baby food that usually do not have additional sugar (Rada-Mendoza et al., 2002a) is low and stays in range of undetectable amount to $1.0 \mathrm{mg} / 100 \mathrm{~g}$

It is possible to avoid excessive formation of HMF even in jams rich in sugar through manipulation of preparation process parameters. It was proven by Cendrowski et al. (2012) in a study where two jams of same sugar content (68\%) were prepared. The sample without addition of citric acid had significantly lower HMF concentration, therefore in jams rich in sugar addition of citric acid would be unfavorable (Cendrowski, 2012).

Rada-Mendoza et al. (2002a; 2004) noted an significant influence of sugar content on the furosine levels. Reduced sugar jams show lower furosine levels than standard jams. Even less furosine can be found in fruit-based baby food (RadaMendoza et al., 2002a).

There is little data on the impact of fruit share on HMF and furosine concentration. Rada-Mendoza et al. (2002b; 2002a) carried out a comparative study of a several samples of commercially available jams from various types of fruit in terms of the influence of fruit share, sugar content, $\mathrm{pH}$ and moisture on the HMF and furosine concentrations. The research showed that the formation of MRPs in jams depends on different factors - not necessarily on the fruit share. To eliminate the possible variability due to the type of fruit, a study on jams made only from peach was carried out and it showed that reduced-sugar jam samples had the lowest levels of furosine. The amount of HMF in these samples varied regardless of the $\mathrm{pH}$, sugar or fruit content. According to the Rada Mendoza et al. (2002b) low HMF contents in fruit-based infant foods, compared with those found in jams, may in part be due to the lower fruit concentration in fruit-based infant foods.

\section{Temperature, pressure and processing time}

Higher temperature levels and long processing periods correspond with an increase in the abundance of Maillard Reaction markers in jams. It is caused by an increase in reactivity between sugars and amino acids. Studies on peach puree proven that darkening of this product is intensified with an increase of temperature and time, with thermal treatment being more influential than the length of heating period (Garza et al., 1999). Moreover, it was noted that both HMF and furosine are formed in higher amount in jams that undergo more severe heat treatment (RadaMendoza et al., 2004).

The pressure is also the factor on which the course of Maillard Reaction depends. There are two major pressure condition types used in the jam production: atmospheric pressure and under the vacuum (Rada-Mendoza et al., 2002a; Korus et al., 2015) conducted an experiment where cooking jam in an open pan and cooking in a vacuum evaporator were compared. The second method allowed the application of lower temperatures but took longer than cooking under the normal pressure. Open pan cooking resulted in 5 times higher HMF concentrations than cooking under vacuum. While storage caused an increase in HMF only in vacuum cooked samples, these concentrations were still notably lower than in open pan cooked jams. It is important to note that in the vacuum cooked samples there was also no loss of polyphenols, lesser loss of flavonoids and anthocyanins (Korus, Jaworska, Bernaś and Juszczak, 2015; Okut et al., 2018) list advantages of vacuum cooking: lower temperatures, a shortened time period and decreased concentration of oxygen during the process. These conditions preserve natural bioactive compounds and the colour of fruit. The obvious disadvantage of this method is limited application in the industrial production only. Okut et al. (2018) developed prototype household vacuum cooking equipment which after optimization lead to achievement of low concentrations of HMF (Okut et al. 2018).

Decreased pressure allows the use of low temperatures, which limits Maillard Reaction's intensity and prevents the loss of natural compounds. However, some beneficial MRPs (e.g. melanoidins) are produced in larger amounts when the temperature is higher (Flores and del Castillo, 2016; Garza et al., 1999; Nahid and Niaz, 2015; Tomas et al., 2017).

\section{pH}

The $\mathrm{pH}$ affects reactivity of sugars and amino acids - key compounds in the earliest stage of Maillard Reaction (Martins et al., 2000). The value of $\mathrm{pH}$ in jams depends mostly on the fruit species used in production and on addition of $\mathrm{pH}$ modifiers into the product (Rada-Mendoza $\boldsymbol{e t}$ al., 2002a). In fruit jams and similar products relatively low $\mathrm{pH}$ can be measured: about 2.1-3.9 in jam samples and about 3.7 4.2 in fruit-based baby food (Cendrowski et al., 2011; Rada-Mendoza et al. 2002a; Rada-Mendoza et al., 2004). Low $\mathrm{pH}$ values are linked to intensified formation of HMF in Maillard reaction (Figure 1) (Cendrowski, 2012; Kopjar, Đurkan and Piližota, 2010). For example, bitter orange jam has much lower $\mathrm{pH}$ and exhibits higher levels of HMF compared to sweet orange jam (Kopjar $\boldsymbol{e t}$ al., 2010). Under acidic conditions hydroxymethylfurfural is formed even at low temperatures (Cendrowski, 2012). Baby food show lower amounts of HMF by mean value than jams probably because of their higher $\mathrm{pH}$ (Rada-Mendoza et al. 2002b).

Rada-Mendoza et al. (2002a) noted differences between furosine levels in jams obtained from various fruits which are attributed partially to the differences of $\mathrm{pH}$ in the samples. Banana and fig jams which have higher $\mathrm{pH}$ values than many other processed fruit products have higher furosine levels (Rada-Mendoza et al., 2002a). However the addition of citrus juice causes the formation of higher furosine levels in baby food (Rada-Mendoza et al., 2002a). Furthermore, three out of six examined samples with citrus juice presented an undetectable quantity of hydroxymethylfurfural (Rada-Mendoza et al., 2002b).

Nonetheless, if comparing the influences of different factors on the formation of Maillard Reaction markers in thermally treated fruit products, it can be concluded that HMF synthesis seems to be less dependent on the jam's $\mathrm{pH}$ and sugar content than on temperature and heating time (Rada-Mendoza et al., 2002b; Vorlova et al., 2006).

\section{Storage conditions}

Prolonged storage can alter compounds formed in the Maillard Reaction too During 12 months of storage browning in jams still occurs, more noticeably at higher temperature. Increases in amount of HMF and furosine were observed by Rada-Mendoza et al. (2004), but HMF quantity seemed to be more dependent on temperature than furosine quantity. During storage of commercial jams HMF amount significantly changed:

from $0.6 \mathrm{mg} / 100 \mathrm{~g}$ of product to $2.5 \mathrm{mg} / 100 \mathrm{~g}$ of product in $20^{\circ} \mathrm{C}$ from $0.6 \mathrm{mg} / 100 \mathrm{~g}$ of product to $35.2 \mathrm{mg} / 100 \mathrm{~g}$ of product in $35^{\circ} \mathrm{C}$ (Rada-Mendoza et al., 2004).

This finding, supported by other authors, Djaoudene et al. (2016), determined $144 \% \mathrm{HMF}$ content increase in $25^{\circ} \mathrm{C}$ and $169 \%$ in $35^{\circ} \mathrm{C}$ in orange jam after 30 days (Djaoudene and Louaileche, 2016). In many other jam samples HMF content increases during storage too and rate of this change depends on temperature (Aslanova, Bakkalbasi and Artik, 2010; Kopjar et al., 2010; Touati, Tarazona- 
Díaz, Aguayo and Louailechea, 2013). Cendrowski et al. (2011) noticed the rise in HMF and furfural levels in jams made of rose petals, black currant and blueberry. Refrigerated samples shown significantly lower HMF concentrations (Cendrowski et al., 2011; Cendrowski, 2012). Fruit-based baby food undergo similar changes too (Rada-Mendoza et al., 2004). Moreover, concentrations of HMF and furfural increase with simultaneous decrease in ascorbic acid and there is a linear relationship between these two phenomena. This might be caused by ascorbic acid degradation leading to the formation of furfural (Cendrowski $\boldsymbol{e t}$ al. 2011)

Rada-Mendoza et al. (2004) state that simultaneous evaluation of HMF and furosine contents in jams and fruit-based baby food can help in the detection of incorrect storage conditions or overheating during preparation, as furosine formation is less sensitive to the high temperatures (Rada-Mendoza et al., 2004)

\section{INFLUENCE OF MR ON THE QUALITY OF FOOD}

Heat treatment and/or prolonged storage conditions might partially decrease the amount of biochemical components of foodstuff such as vitamins and nutrients and - unfortunately - at the same time enhance the content of MRPs (Kesić et al., 2014 Shapla et al., 2018). HMF, which occurs at a very low concentration or is not detected in fresh products, can serve as the factor of quality and freshness of sugar rich foodstuffs. The Codex Alimentarius Standard Commission set the maximum concentration for HMF in honey at $4.0 \mathrm{mg} / 100 \mathrm{~g}$ (with a higher limit of 8.0 $\mathrm{mg} / 100 \mathrm{~g}$ for honeys originating from tropical countries) to ensure that the product has not undergone extensive heating during processing and is safe for the consumers (Codex Alimentarius Commission, 2001). HMF content in honey is an important parameter for the analysis of the quality of honey, its freshness, antioxidant activity, as well as its nutritional value. Some of the studues had also focsued on the influence of storage time. on the quality of honey. It was shown that samples of 4 year old honey contains on average $52.44 \%$ higher HMF amount compared to fresh honey samples (Kesić et al., 2014). It is worth noting that for jams no standard describing the acceptable content of HMF has been introduced yet though its concentrations can be higher in fruit products than in honey (Table1) During the Maillard Reaction some biological active ingredients of food undergo degradation, and among these are valuable vitamins, polyphenols and amino acids. Many studies note loss of vitamin C (ascorbic acid) during the preparation of jams (Aksay, Tokbaș, Arslan and Çınar, 2018; Cendrowski et al., 2011; Henning and Glomb, 2016; Kopjar et al., 2010). For example Aksay et al. (2018) evaluated the vitamin $\mathrm{C}$ concentration of $0.11 \mathrm{mg} / 100 \mathrm{~g}$ in fresh mandarin fruit and $0.07 \mathrm{mg} / 100 \mathrm{~g}$ in mandarin jam (Aksay et al., 2018). Ascorbic acid can directly undergo degradation to HMF and furfural (Henning and Glomb, 2016). A correlation between furfural concentration and ascorbic acid loss in black currant and blueberry jams was reported by Cendrowski et al. (2011). Initial addition of ascorbic acid into fruits during the preparation of jam causes an increase in final HMF content (Kopjar et al., 2010).

It is important to underline the fact, that as phenolic content is unfortunately decreased in jams compared to fresh fruit, the final product still has a notable antioxidant capacity (Aksay $\boldsymbol{e t}$ al., 2018).

The Maillard Reaction uses amino acids contained in the food product which leads to the loss of protein content, thus lowering nutritive value of product. During the reaction amino acids can be destroyed and become biologically inactive (essential amino acids undergo these changes too). Depending on the conditions of the experiment, both decrease and increase of protein digestibility can be observed (Teodorowicz, van Neerven and Savelkoul, 2017). Whole proteins undergo cross-linking by MRPs, thus even some enzymes become less active (Martins $\boldsymbol{e}$ al., 2000; Nahid and Niaz, 2015). Sabater et al. (2018) state that control of furosine levels is crucial for evaluation of the influence of heat treatment on the loss of lysine and the general loss of nutritive value in infant foodstuffs (Sabater et al., 2018).

Flores et al. (2016) compared home-made strawberry jam, industrially obtained jam and fresh fruit to evaluate the presence of antioxidative compounds. The authors point out several advantages of home-made jam over the industrialy processed jam, such as lower antioxidants loss, the preservation of natura compounds and smaller amount of carcinogenic MRPs. It is attributed to less severe thermal treatment of fruit (Flores and del Castillo, 2016).

\section{INFLUENCE OF MRPs ON ORGANISM}

The importance of a balanced diet has become one of the priorities of modern life.The general society's awareness and knowledge regarding the influence of many chemical compounds formed in food during processing (also under home conditions) on human health had lead to the need for further investigation (Lund and Ray, 2017). The impact of Maillard Reaction Products on human health definitely gets more and more scientific attention since many different MRPs are present in a wide variety of foodstuffs, including products designed for infants (Plaza et al., 2016; Rada-Mendoza et al., 2004; Vorlova et al., 2006). The large body of evidence has demonstrated that diets rich in MRPs may lead to the increase of oxidative stress, inflammation, incidence of cardiovascular diseases or even the alteration of glucose metabolism (ALjahdali and Carbonero, 2017; Delgado-
Andrade, 2014; Labuz-Roszak et al., 2018; Nogajczyk, Szumska, Kumaszka and Tyrpień-Golder, 2015; Šebeková and Brouder Šebeková, 2018)

The problem goes even further when infants' diets, which are supposed to be rich in fruit and fruit based products, are taken into account (Plaza et al., 2016). Such an early exposure to MRPs will definitely not remain neutral to the organism (Östman, 2016). Moreover, there are studies which have suggested the hypothesis of the connection of exposure to some MRPs in early childhood with obesity and the increased risk of other cardiovascular and metabolic diseases in later life (Gupta and Uribarri, 2016; Merciq et al., 2010).

Among the MRPs that have been reported to have harmful properties are HMF and furosine, two compounds that have been detected in jams (Monien et al., 2009; Saeed, Wang and Zheng, 2017). HMF is present in many food products including these designed for small children, for example gruel, biscuits and fruit based-food (Tab 1) (Plaza et al., 2016; Rada-Mendoza et al., 2002a; Rada-Mendoza et al., 2002b; Švecová and Mach, 2017).

Scientific data provides contradictory information on hydroxymethylfurfural's safety. In vitro studies suggest that it is not dangerous in low amounts, such as 0.5 $-1 \mathrm{mg} / \mathrm{kg}$ body weight, though it poses a serious health risk in concentrations much higher than present in processed food. It was proven that HMF in high concentrations shows irritating properties (Murkovic and Pichler, 2006). Some researchers have estimated daily exposure to HMF and, for example, in the Czech Republic exposure reaches up to $1.11 \mathrm{mg}$ per inhabitant and in Spain it ranges from $2.1 \mathrm{mg}$ even up to $23 \mathrm{mg}$ (Rufián-Henares and de la Cueva, 2008). This amoun should not pose any risk to a healthy adult person (Vorlova et al., 2006) but still scientists do not know the exact impact on the organism of very young children, if the longtime exposure from different sources is taken into account (Kutlu, 2016) According to the study conducted on Norwegian women and men jams are not the main soured of dietary HMF (with most of the dietary HMF coming from coffee, milk and juices) (Husøy et al., 2008).

The controversy regarding the health risk of HMF and especially its safe levels may be caused by the fact that HMF can be converted into sulfoxymethyl-2 furfural (SMF) which may induce toxic and mutagenic effect. According to Monien et al. (2009) significant amounts of SMF can be created in human body after ingesting HMF (Monien et al., 2009). The scientists observed this phenomenon in mice and since the metabolism of HMF probably follows the same pathways of biotransformation as furfural in all mammalians (Capuano and Fogliano, 2011) it does not exclude risk of the SMF formation in humans. SMF shows carcinogenic properties as it can react not only with DNA (forming adducts) but also with other macromolecules (Monien et al., 2009; Monien et al., 2012; Murkovic and Pichler, 2006).

HMF itself is too small compound to be recognized by the immune system ( $\mathrm{T}$ cells) but it has been proven that it is capable of immunomodulation since it can bind to large peptides and then interact with T-cells_(Lin et al., 2016). Moreover, furfural (which is also present in jams and gruel for infants) (Plaza et al., 2016) is able to modulate the immune response and can act as neo-epitope (Lin et al., 2016) This shows the immunosensitizing potential of these MRPs which can lead to autoimmune disorders. Alternation of food proteins immunogenicity by MRPs is considered (Teodorowicz et al., 2017)

The another MRP - furosine - is widely present in many food products, including infant fruit food and formulas (Table 2) (Rada-Mendoza et al., 2002a; Sabater $\boldsymbol{e}$ al., 2018). However it is little known about its effect on human health, especially longtime exposure. It has been proven so far that furosine reduces cell viability in human cell cultures and causes DNA damage, as well as carcinogenesis in neuroblastoma and kidney epithelia cells ( $\mathbf{L i}$, Xing, Wang and Zheng, 2018; Saeed et al., 2017). While the damage does not lead to increased mutagenicity it is possible that furosine rather causes apoptotic cell death than mutations leading to carcinogenesis (Saeed et al., 2017). In mice models furosine was proven to be toxic towards the kidney and liver and affected count of leukocytes, lymphocytes, neutrophils, red blood cells and blood palateles (Li et al., 2018). These early findings might help us to better understand the risk assessment and provide the evidence for further food safety regulations regarding MRPs occurrence.

Not all MRPs have negative effects on human health. Among MRPs some compounds are beneficial for health have been identified. These include melanoidins, which have antioxidative and antibiotic properties (since they contain catechol and reductone groups) (Delgado-Andrade, Seiquer, Haro, Castellano and Navarro, 2010; Šebeková and Brouder Šebeková, 2018). The properties of these compounds depend strongly on the product processing conditions (e.g. the higher temperature of food processing the higher amount of melanoidins will be generated). Furthermore it was proven that, the intake of melanoidins can also reduce fat accumulation and oxidative stress exposure (Šebeková and Brouder Šebeková, 2018). The missing information regarding melanoidins is how they interact with different molecules and microbiota inside the gastrointestinal tract (ALjahdali and Carbonero, 2017).

It is known that MRPs reduce the activity of oxidoreductases (tyrosinases and polyphenol oxidases - PPOs). The mentioned enzymes oxidize endogenous phenolic compounds present in fruits. Activity of some MRPs preserves these phenolic compounds and prevents enzymatic browning in food. Moreover, phenolic compounds such as flavones and flavonoids are inhibitors of mutagens heterocyclic amines - which are produced in the Maillard Reaction too. In some 
food products the addition of sugar makes them more resistant to oxidative rancidity (Janoszka, 2010; Manzocco, Calligaris, Mastrocola, Nicoli and

Table 2 Exemplary experiments focusing on the Maillard Reaction chemical markers (HMF, furfural and furosine) evaluation

Examined material Sugar content

$[\mathrm{mg} / 100 \mathrm{~g} \mathrm{of}$ product]

Jams with sugar content $\leq 40 \%$

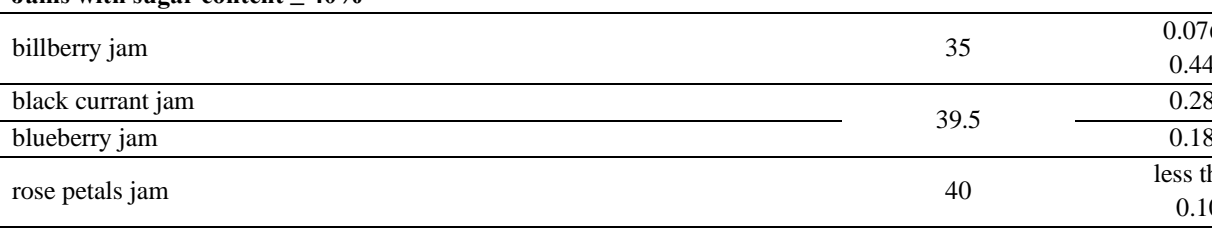

peach jam

$31-40$

40

pineapple jam

40

$31-40$

peach jam

Jams with sugar content $>40 \%$ and $<60 \%$

strawberry jam

apricot jam

strawberry jam

cherry jam

sour cherry jam

raspberry jam

peach jam

jams obtained from plum, pineapple, sweet orange, apricot, strawberry,

mixture of fruit, banana, tropical fruit, lemon

peach jams

jams obtained from plum, pineapple, sweet orange, apricot, strawberry,

mixture of fruit, banana, tropical fruit, lemon

Jams with sugar content $\geq 60 \%$

peach jam

sweet and sour orange, lemon, apple, apricot, mulberry, mixture of fruit,

bilberry, fig

peach jams

sweet and sour orange, lemon, apple, apricot, mulberry, mixture of fruit,

bilberry, fig

peach jam

jams obtained from apricot, peach red currant, strawberry

apricot jam

rose petals jam

orange jam

Jams and fruit-based baby food with unknown content of sugar

fruit-based baby food

\section{strawberry jam}

raspberry jam

peach jams prepared in the laboratory

$$
\text { various jams }
$$

sweet orange jam

bitter orange jam

$$
\text { plum jam }
$$

jams obtained from apple, apricot, carrot, black cherry, pumpkin, and

mango

various jams

plum jam
$41.8-54.6$

$\begin{array}{cc}41.8-54.6 & 1.1 \\ & 7.4 \\ 45.4 & 3.083 \\ 47.5 & 2.039 \\ 53.8 & 3.418 \\ 43 & 0.87 \\ 53 & 1.75 \\ 42-55 & \end{array}$

$42-55$

$47-55$

$42-55$

$47-55$

$\geq 60$

$60-63$

$60-63$

$60-63$

$60-63$

$60-65$

$63.2-66.6$

68

69

(1)

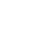

N/A

N/A

N/A

N/A

N/A

N/A

N/A

N/A

N/A

N/A

N/A

N/A

N/A

N/A

N/A
HMF

.076

0.445

0.187

0.10

Furosine [mg/

$100 \mathrm{~g}$ of protein]

Reference

(Korus et al., 2015)

(Cendrowski et al., 2011)

(Cendrowski and Mitek

2012)

(Rada-Mendoza et al., 2002a)

(Rada-Mendoza et al., 2002a)

(Rada-Mendoza et al., 2002b)

(Okut et al., 2018)

(Aslanova , Bakkalbasi and Artik, 2010)

(Vorlova et al., 2006)

(Rada-Mendoza et al., 2002a)

(Rada-Mendoza et al., 2002b)

(Rada-Mendoza et al., 2004)

(Rada-Mendoza et al., 2002a)

(Rada-Mendoza et al., 2002b)

(Vorlova et al., 2006)

(Touati et al., 2013)

(Cendrowski and Mitek

2012)

(Djaoudene and

Louaileche, 2016)

1.8

(Rada-Mendoza et al., 2004)

(Rada-Mendoza et al., 2002a)

(Rada-Mendoza et al., 2002b)

(Vorlova et al., 2006)

(Husøy et al., 2008)

(Rada-Mendoza et al., 2004)

(Baltaci and Akşit,

2016)

(Kopjar, Đurkan and

Piližota, 2010)

(Constantin et al., 2018)

(Jalili and Ansari,

2015)

(Makawi et al., 2009)

(Murkovic and Pichler,

2006) 
The chemical pathways of MRPs in food products are relatively well-known, but so far the biological aspects and the impact of these compounds on the human organism contains many gaps to be filled. As fruit and fruit derivatives are recognized as an element of well-balanced diet, it is important to evaluate the influence of Maillard reaction on their safety. Fruit-rich diet is linked to a lower chronic diseases risk and reduced cancer risk (Cendrowski et al., 2011; Cendrowski, 2012; Flores and del Castillo, 2016; Tomas et al., 2017). Among variety of Maillard Reaction Products, desirable and undesirable compounds can be found. The presence of some mutagenic compounds depends significantly on the pathway taken by the reaction. An understanding of the process is therefore a key to estabilish the optimal conditions in the processing of fruit (Martins et al. 2000).

\section{CONCLUSION}

The Maillard Reaction is an elaborate network of chemical transformations which leads to the formation of many MRPs, including melanoidins, brown substances responsible for darkening food during e.g. roasting. Some MPRs are believed to pose a risk to health in high concentrations. The reaction itself leads to lowering nutritional value of foodstuffs. Therefore, research in field of Maillard Reaction occurrence in fruit products is reasonable, as many of them are an essential part of a balanced diet and children nourishment. While Maillard reaction was widely evaluated in many food products, few studies have focused on jams and fruit-based baby food.

Fruit jams and fruit-based baby food contain ingredients that undergo Maillard Reaction during their preparation and storage. Long heating periods and the abundance of sugar typical for these products favor Maillard reaction occurrence. At low $\mathrm{pH}$ the characteristic for fruit the MR pathway leads to hydroxymethylfurfural formation in jams and other fruit derivatives. Thus, HMF can be used as Maillard reaction marker in fruits products, along with other compounds: furosine and furfural.

Acknowledgments: This work was supported by KNW-1-148/K/8/0 project of Medical University of Silesia in Katowice. Authors declare no conflict of interest.

\section{REFERENCES}

ALJAHDALI, N., CARBONERO, F. 2017. Impact of Maillard reaction products on nutrition and health: Current knowledge and need to understand their fate in the human digestive system. Critical Reviews in Food Science and Nutrition, 13, 1-14. https://doi.org/10.1080/10408398.2017.1378865

AKSAY, S., TOKBAŞ, H., ARSLAN, R., ÇINAR, F. 2018. Some physicochemical properties of the whole fruit mandarin jam. Turkish Journal of Agriculture - Food Science and Technology, 6(5)632-635. https://doi.org/10.24925/turjaf.v6i5.632-635.1948

ASLANOVA, D., BAKKALBASI, E., ARTIK, N. 2010. Effect of storage on 5hydroxymethylfurfural (HMF) formation and color change in jams. International Journal of Food Properties, 13(4)904-912. https://doi.org/10.1080/10942910902908896

BALTACI, C., AKŞIT, Z. 2016. Validation of HPLC method for the determination of 5-hydroxymethylfurfural in pestil, köme, jam, marmalade and pekmez. Hittite Journal of Science and Engineering, 3(2)91-97. https://doi.org/10.17350/HJSE1903000003

BHARATE, S. S., BHARATE S. B. 2014. Non-enzymatic browning in citrus juice: chemical markers, their detection and ways to improve product quality. Journal of Food Science and Technology, 51(10)2271-2288. https://doi.org/10.1007/s13197-012-0718-8

CAPUANO, E., FOGLIANO, V. 2011. Acrylamide and 5-hydroxymethylfurfura (HMF): A review on metabolism, toxicity, occurrence in food and mitigation strategies. LWT - Food Science and Technology, 44(4)793-810. https://doi.org/10.1016/j.1wt.2010.11.002

CENDROWSKI, A., ŚCIBISZ, I., MITEK, M. 2011. Wpływ warunków przechowywania na zawartość hydroksymetylofurfuralu, furfuralu i kwasu askorbinowego $\mathrm{w}$ dżemach $\mathrm{z}$ owoców jagodowych [Effect of storage conditions on the content of hydroxymethylfurfural, furfural, and ascorbic acid in berry jams]. Żywność: nauka - technologia - jakość, 6(79)155-166.

CENDROWSKI, A., MITEK, M. 2012. Wpływ przechowywania na wybrane parametry jakościowe konfitur z płatków róży owocowej [Effect of storage on choosen quality parameters of confitures from petals of Rosa rugosa]. Zeszyty Problemowe Postępów Nauk Rolniczych, 570, 7-18.

CODEX ALIMENTARIUS COMMISSION. (2001). Report of the Seventh Session of the Codex Committee on Sugars (ALINORM 01/25). Retrieved from Food and Agriculture Organization of the United Nations website: www.fao.org/input/download/report/277/Al01 25e.pdf

CONSTANTIN, O. E., RÂPEANU, G., KUKUROVÁ, K., TURTURICĂ, M., DUBOVÁ, Z., TOBOLKOVÁ, B., ... CROITORU, C. 2018. Antioxidative capacity of and contaminant concentrations in processed plum products consumed in Romania. Journal of Food Protection, 81(8)1313-1320. 408 https://doi.org/10.4315/0362-028X.JFP-18-066

DA SILVA, P. M, GAUCHE, C., GONZAGA, L. V., COSTA, A. C. O., FETT, R 2016. Honey: Chemical composition, stability and authenticity, Food Chemistry, 196:309-323. http://dx.doi.org/10.1016/j.foodchem.2015.09.051

DELGADO-ANDRADE, C., SEIQUER, I., HARO, A., CASTELLANO, R. NAVARRO, M. P. 2011. Development of the Maillard reaction in foods cooked by different techniques. Intake of Maillard-derived compounds. Food Chemistry 122(1)145-153. https://doi.org/10.1016/j.foodchem.2010.02.031

DELGADO-ANDRADE, C. 2014. Maillard reaction products: some considerations on their health effects. Clinical Chemistry and Laboratory Medicine, 52(1)53-60. https://doi.org/10.1515/cclm-2012-0823

DJAOUDENE, O., LOUALIECHE, H. 2016. Effect of storage time and temperature on the nutritional quality of commercial orange jam. SDRP Journal of Food Science and Technology, 1(2)78-84. https://doi.org/10.25177/JFST.1.2.5 ERBERSDOBLER, H. F., SOMOZA, V. 2007. Forty years of furosine - Forty years of using Maillard reaction products as indicators of the nutritional quality of foods. Molecular Nutrition Food Research, 51(4)423-430. https://doi.org/10.1002/mnfr.200600154

FLORES, G., DEL CASTILLO, M. L. R. 2016. Cancer-related constituents of strawberry jam as compared with fresh fruit. Cancers (Basel), 8(1)16 https://doi.org/10.3390/cancers8010016

GARZA, S., IBARZ, A., PAGÂN, J., GINER, J. 1999. Non-enzymatic browning in peach puree during heating. Food Research International, 32(5)335-343. https://doi.org/10.1016/S0963-9969(99)00094-0

GUPTA, A., URIBARRI, J. 2016. Dietary advanced glycation end products and their potential role in cardiometabolic disease in children. Hormone research in padiatrics, 85(5)291-300. https://doi.org/10.1159/000444053

HENNING, C., GLOMB, M. A. 2016. Pathways of the Maillard reaction under physiological conditions. Glycoconjugate journal, 33(4)499-512 https://doi.org/10.1007/s10719-016-9694-y

HUSØY, T., HAUGEN, M., MURKOVIC, M., JÖBSTL, D., STØLEN, L. H., BJELLAAS, T., ... ALEXANDER, J. 2008. Dietary exposure to 5hydroxymethylfurfural from Norwegian food and correlations with urine metabolites of short-term exposure. Food and chemical toxicology: an international journal published for the British Industrial Biological Research Association, 46(12)3697-702. https://doi.org/10.1016/j.fct.2008.09.048

JALILI, M., ANSARI, F. 2015. Identification and quantification of 5hydroxymethylfurfural in food products. Nutrition and Food Sciences Research 2(1)47-53.

JANOSZKA B. 2010. Heterocyclic amines and azaarenes in pan-fried meat and its gravy fried without additives and in the presence of onion and garlic. Food Chemistry., 120,(2), 463-473. https://doi.org/10.1016/j.foodchem.2009.10.039 KESIĆ, A., CRNKIĆ, A., HODŽIĆ, Z., IBRIŠIMOVIĆ, N., ŠESTAN, A. 2014. Effects of botanical origin and ageing on HMF content in bee honey, Journal of Scientific Research \& Reports, 3(8):1057-1066. https://doi.org/10.9734/JSRR/2014/8095

KOPJAR, M., ĐURKAN, I., PILIŽOTA, V. 2010. HMF formation and colour change of bitter orange and sweet orange jams during storage. Croatian Journal of Food Science and Technology, 2(2)11-15.

KORUS, A., JAWORSKA, G., BERNAŚ, E., JUSZCZAK, L. 2015 Characteristics of physico-chemical properties of bilberry (Vaccinium myrtillus $L$.) jams with added herbs. Journal of Food Science and Technology, 52(5)2815-2823. https://doi.org/10.1007/s13197-014-1315-9

KUTLU, T. 2016. Dietary glycotoxins and infant formulas. Türk pediatri arşivi, 51(4)179-185. https://doi.org/10.5152/TurkPediatriArs.2016.2543

LI, H. Y., XING, L., WANG, J. Q., ZHENG, N. 2018. Toxicology studies of furosine in vitro/in vivo and exploration of the related mechanism. Toxicology letters, 291, 101-111. https://doi.org/10.1016/j.toxlet.2018.02.018

LIN, N., LIU, T., LIN, L., LIN, S., ZANG, Q., HE, J., ... JIN, H. 2016. Comparison of in vivo immunomodulatory effects of 5-hydroxymethylfurfural and 5, 5'oxydimethylenebis (2-furfural). Regulatory Toxicology and Pharmacology, 81, 500-511. https://doi.org/10.1016/j.yrtph.2016.10.008

LUND, M. N., RAY, C. A. 2017. Control of Maillard reactions in foods: strategies and chemical mechanisms. Journal of Agricultural and Food Chemistry, 65(23)4537-4552. https://doi.org/10.1021/acs.jafc.7b00882

ŁABUZ-ROSZAK, B., KUMASZKA, B., DAMASIEWICZ-BODZEK, A., NOWAK, A., TYRPIEŃ-GOLDER, K. (2018, March 22-25). The role of advanced glycation of proteins in the aetiopathogenesis of multiple sclerosis. Paper presented at 12th World Congress on Controversies in Neurology (CONY) Warsaw, Poland, Pol.Przegl.Neurol., 14, Supl.A, 127.

MAKAWI, S. Z. A., TAHA, M. I., ZAKARIA, B. A., SIDDIG, B., MAHMOD, H., ELHUSSEIN, A. R. M., KARIEM, E. A. G. 2009. Identification and quantification of 5-hydroxymethyl furfural HMF in some sugar-containing food products by HPLC. Pakistan Journal of Nutrition, 8(9)1391-1396. https://doi.org/10.3923/pjn.2009.1391.1396

MANZOCCO, L., CALliGARIS, S., MASTROCOLA, D., NICOLI, M. C, LERICI, C. R. 2001. Review of non-enzymatic browning and antioxidant capacity 
in processed foods. Trends in Food Science and Technology, 11(9-10)340-346. https://doi.org/10.1016/S0924-2244(01)00014-0

MARTINS, S. I. F. S., JONGEN W. M. F., VAN BOEKEL M. A. J. S. 2000. A review of Maillard reaction in food and implications to kinetic modeling. Trends in Food Science and Technology, 11(9-10)364-373. https://doi.org/10.1016/S0924-2244(01)00022-X

MERICQ, V., PICCARDO, C., CAI, W., CHEN, X., ZHU, L., STRIKER, G.E., .. URIBARRI, J. 2010. Maternally transmitted and food-derived glycotoxins: a factor preconditioning the young to diabetes? Diabetes Care, 33(10)2232-2237. https://doi.org/10.2337/dc10-1058

MEURILLON, M., ENGEL, E. 2016. Mitigation strategies to reduce the impact of heterocyclic aromatic amines in proteinaceous foods. Trends in Food Science and Technology, 50, 70-84. https://doi.org/10.1016/j.tifs.2016.01.007

MONIEN, B. H., FRANK, H., SEIDEL, A., GLATT, H. 2009. Conversion of the common food constituent 5-hydroxymethylfurfural into a mutagenic and carcinogenic sulfuric acid ester in the mouse in vivo. Chemical Research in Toxicology, 22(6)1123-1128. https://doi.org/10.1021/tx9000623

MONIEN, B. H., ENGST, W., BARKNOWITZ, G., SEIDEL, A., GLATT, H 2012. Mutagenicity of 5-Hydroxymethylfurfural in V79 cells expressing human SULT1A1: identification and mass spectrometric quantification of DNA adducts formed. Chemical Research in Toxicology, 25(7)1484-1492. https://doi.org/10.1021/tx300150n

MURKOVIC, M., PICHLER, N. 2006. Analysis of 5-hydroxymethylfurfual in coffee, dried fruits and urine. Molecular Nutrition and Food Research, 50(9)842846. https://doi.org/10.1002/mnfr.200500262

NAHID, T., NIAZ, M. 2015. Food processing and Maillard reaction products: effect on human health and nutrition. International Journal of Food Science, 2015 1-6. https://doi.org/10.1155/2015/526762

NOGAJCZYK, A., SZUMSKA, M., KUMASZKA, B., TYRPIEŃ-GOLDER, K. 2015. Methods of determination of pentosidine - the advanced glycation endproduct of proteins. Aparatura Badawcza i Dydaktyczna, 20(3), 158-165.

OKUT, D., DEVSEREN, E., KOÇ M., OCAK, Ö. Ö., KARATAȘ, H., KAYMAKERTEKIN, F. 2018. Developing a vacuum cooking equipment prototype to produce strawberry jam and optimization of vacuum cooking conditions. Journal of Food Science and Technology, 55(1)90-100. https://doi.org/10.1007/s13197. 017-2819-X

PARKER, J. K. 2012. The kinetics of thermal generation of flavour. Science of Food and Agriculture, 93(2)197-208. https://doi.org/10.1002/jsfa.5943

PLAZA, M., ÖSTMAN, E., TAREKE, E. 2016. Maillard reaction products in powder based food for infants and toddlers. European Journal of Nutrition and Food Safety, 6(2)65-74. https://doi.org/10.9734/EJNFS/2016/19150

POWIDŁA ŚLIWKOWE ŁOWICKIE [Plum jam from Łowicz]. (2018, September 9) Retrieved from https://www.gov.pl/web/rolnictwo/powidlasliwkowe-lowickie

POWIDŁA ŚLIWKOWE Z WEGIEREK [Plum jam made of „węgierka” plum]. (2018, September 26). 2 Retrieved from https://www.gov.pl/web/rolnictwo/powidla-sliwkowe-z-wegierek

RADA-MENDOZA, M., OLANO, A., VILLAMIEL, M. 2002a. Furosine as indicator of Maillard reaction in jams and fruit-based infant foods. Journal of Agricultural and Food Chemistry, 50(14)4141-4145. https://doi.org/10.1021/jf0201024

RADA-MENDOZA, M., OLANO, A., VILLAMIEL, M. 2002b. Determination of hydroxymethylfurfural in commercial jams and in fruit-based infant foods. Food Chemistry, 79(4)513-516. https://doi.org/10.1016/S0308-8146(02)00217-0

RADA-MENDOZA, M., LUZ SANTZ, OLANO, A., VILLAMIEL, M. 2004. Formation of hydroxymethylfurfural and furosine during the storage of jams and fruit-based infant foods. Food Chemistry. 85(4)605-609. https://doi.org/10.1016/j.foodchem.2003.07.002

RUFIÁN-HENARES, J. A., DE LA CUEVA, S. P. 2008. Assessment of hydroxymethyl furfural intake in the Spanish diet. Food Additives and Contaminants: Part A, 25(11)1306-1312. https://doi.org/10.1080/02652030802163406

SABANCI, S., CEVIK, M., COKGEZME, O. F., YILDIZ, H., ICIER, F. 2018 Quality characteristics of pomegranate juice concentrates produced by ohmic heating assisted vacuum evaporation. Science of Food and Agriculture, 99(5)25892595. https://doi.org/10.1002/jsfa.9474

SABATER, C., MONTILLA, A., OVEJERO, A., PRODANOV, M., OLANO, A., CORZO, N. 2018. Furosine and HMF determination in prebiotic-supplemented infant formula from Spanish market. Journal of Food Composition and Analysis 66, 65-73. https://doi.org/10.1016/j.jfca.2017.12.004

SAEED, Y., WANG, J. Q., ZHENG, N. 2017. Furosine induces DNA damage and cell death in selected human cell lines: a strong toxicant to kidney Hek-293 cells. Food Science and Biotechnology, 26(4)1093-1101. https://doi.org/10.1007/s10068-017-0131-1

SHAPLA, U. M., SOLAYMAN, M., ALAM, N., KHALIL, M. I., GAN, S. H. 2018. 5-Hydroxymethylfurfural (HMF) levels in honey and other food products: effects on bees and human health, Chemistry Central Journal, 12(1)35. https://doi.org/10.1186/s13065-018-0408-3
STEBER F., KLOSTERMEYER, H. 1987. Heat treatment of fruit preparations and jams, and monitoring its efficacy. Molkerei Zeitung Welt der Milch, 41, 289-290, 292-295.

ŠEBEKOVÁ, K., BROUDER ŠEBEKOVÁ, K. 2018. Glycated proteins in nutrition: Friend or foe? Experimental gerontology, 117, 76-90. https://doi.org/10.1016/j.exger.2018.11.012

ŠVECOVÁ, B., MACH, M. 2017. Content of 5-hydroxymethyl-2-furfural in biscuits for kids. Interdisciplinary toxicology, 10(2)66-69. https://doi.org/10.1515/intox-2017-0011

TEODOROWICZ, M., VAN NEERVEN, J., SAVELKOUL, H. 2017. Food processing: The influence of the Maillard reaction on immunogenicity and $\begin{array}{llll}\text { allergenicity of food proteins. } & \text { Nutrients, } & \text { 9(8)835. }\end{array}$ https://doi.org/10.3390/nu9080835

TOMAS, M., TOYDEMIR, G., Boyacioglu, D., Hall, R. D., Beekwilderd, J., Capanoglu, E. 2017. Processing black mulberry into jam: effects on antioxidant potential and in vitro bioaccessibility. Journal of the science of food and agriculture, 97(10)3106-3113. https://doi.org/10.1002/jsfa.8152

TOUATI, N., TARAZONA-DÍAZ, M. P., AGUAYO, E., LOUAILECHEA, H. 2013. Effect of storage time and temperature on the physicochemical and sensory characteristics of commercial apricot jam. Food Chemistry, 145, 23-27. https://doi.org/10.1016/j.foodchem.2013.08.037

VORLOVÁ, L., BORKOVCOVÁ, I., KALÁBOVÁ, K., VECEREK, V. 2006. Hydroxymethylfurfural contents in foodstuffs determined by HPLC method. Journal of Food and Nutrition Research, 45(1)34-38. 